\title{
Pumpkin Yield and Disease Response to Amending Soil with Silicon
}

\author{
Joseph R. Heckman ${ }^{1}$ \\ Department of Plant Biology and Pathology, Rutgers, The State University of \\ New Jersey, 59 Dudley Road, Foran Hall, New Brunswick, NJ 08901-8520
}

\section{Steve Johnston ${ }^{2}$ \\ Rutgers Agricultural Research \& Extension Center, 121 Northville Road, Bridgeton, NJ 08302}

\section{Win Cowgill ${ }^{3}$ \\ Department of Agricultural and Resource Management Agents, Extension Center, P.O. Box 2900, Flemington, NJ 08820-2900}

Additional index words. powdery mildew, Cucurbita pepo, liming material, soil $\mathrm{pH}$

\begin{abstract}
Field experiments were conducted with Cucurbita pepo L. 'Howden' pumpkin in 2000 to 2001 to study the effects of silicon (Si) amendment of soil with and without the use of fungicides on yield and powdery mildew suppression. A Quakertown silt loam soil (fine-loamy, mixed, mesic Typic Hapludult) with an initial soil pH of 5.7 was amended with either $\mathrm{CaCO}_{3}$ or $\mathrm{CaSiO}_{3}$ at the rate of $7840 \mathrm{~kg} \cdot \mathrm{ha}^{-1}$ of calcium carbonate equivalent. Fungicides were applied on a 7-10 day schedule to half of the plots as a $2 \times 2$ factorial, beginning when the first powdery mildew lesions were detected in the field. Silicon amendment increased pumpkin yield by $60 \%$ in 2000 but $\mathrm{Si}$ did not influence yield in 2001. Infection with bacterial leaf spot reduced yield on all plots in 2001. Fungicide applications increased yield only in 2001. In 2000, Si amendment had the effect of delaying foliage senescence but it was not clear if this was the result of an effect of Si on disease activity or crop physiology. In Aug. 2001, Si amendment generally reduced powdery mildew severity, but only at the $10 \%$ level of significance. In Sept. 2001, the combination of Si amendment plus fungicide application was more effective in reducing powdery mildew severity than either Si or fungicide alone. Silicon amendment resulted in a 5-fold increase in plant Si concentration. Soil $\mathrm{pH}$ measured after harvest in 2001 indicated no significant difference in $\mathbf{~} H$ between plots amended with $\mathrm{CaCO}_{3}(\mathrm{pH}=6.8)$ and $\mathrm{CaSiO}_{3}(\mathrm{pH}=6.9)$. In New Jersey, the cost of these liming materials is similar. Thus, the selection of $\mathrm{CaSiO}_{3}$ as a liming material as needed for soil $\mathrm{pH}$ correction has the potential benefits of suppressing powdery mildew and increasing pumpkin yield without increasing the cost of production.
\end{abstract}

Growing pumpkins has become highly profitable for many New Jersey growers by utilizing "entertainment type farm marketing." Powdery mildew caused by Podosphaera (sect. Sphaerotheca) xanthii (Castagne) U. Braun \& $\mathrm{N}$. Shishkoff occurs annually on pumpkin in New Jersey, and can limit production if not properly managed with varietal resistance and fungicide use. Downy mildew (Pseudoperonospora cubensis (Berk. \& M.A. Curtis) Rostovzev and bacterial leaf spot (Xanthomonas

Received for publication 3 June 2002. Accepted for publication 31 Dec. 2002. This research was supported by the New Jersey Agricultural Experiment Station. Additional funding was provided by Pennsylvania Vegetable Marketing and Research Program and The Charles E. and Lena Maier Vegetable Research grants. The technical assistance of Dennis Haines, Jean Riling, Kristian Holmstrom, Martha Maletta, and Quin Obrienis is gratefully acknowledged. Stephen Johnston died tragically as a result of an accident in April 2003 after the completion of this article. We dedicate this article in remembrance of Dr Johnston, a renowned authority in plant pathology and a valued friend and colleague. ${ }^{1}$ Extension Specialist in Soil Fertility, to whom reprint requests should be addressed; e-mail: heckman@aesop.rutgers.edu.

${ }^{2}$ Disease Management in Vegetable Crops.

${ }^{3}$ County Agricultural Agent. campestris pv. cucurbitae (Bryan) Dye do not occur annually; however, in years when either of these diseases occur, pumpkins can be severely impacted. Consequently, fungicide and bactericide preventative applications are recommended in most years. The high price of weekly fungicide applications significantly increases the cost of production. Fungicide costs can approach $\$ 400 /$ ha annually for product, equipment and labor. Consequently, reducing fungicide use is a priority for pumpkin growers.

Fertilization with silicon may provide a new approach to disease control on pumpkin. Silicon nutrition has been shown to have a role in suppression of powdery mildew on crops related to pumpkin such as cucumber, muskmelon, and zucchini (Menziesas et al., 1992). In addition to disease suppression, the benefits of silicon fertilization may include increased yield, resistance to insects, and tolerance to drought stress (Belanger et al., 1995; Epstein, 1994, 1999; Hamel and Heckman, 1999; Savant et al., 1997).

The liming material sold as Reclime (Recmix, Pa.), is a byproduct of the stainless steel industry and contains primarily $\mathrm{CaSiO}_{3}$. Because this product has a calcium carbonate equivalent of $90 \%$ it may be used as an alterna- tive liming agent to neutralize soil acidity and at the same time supply Si to crops.

Objectives of this study were to 1) evaluate the effect of adding Si to soil with and without the use of fungicides on powdery mildew severity and pumpkin yield, and 2) compare the effects of $\mathrm{CaCO}_{3}$ vs. $\mathrm{CaSiO}_{3}$ on concentration of $\mathrm{Si}$ in pumpkin plant tissue and change in soil $\mathrm{pH}$.

\section{Materials and Methods}

Field experiments were conducted in 2000 and 2001 with 'Howden' pumpkin on the same set of plots established with a single application of $\mathrm{CaCO}_{3}$ or $\mathrm{CaSiO}_{3}$ in June 2000 at the Rutgers Snyder Research and Extension Farm, Pittstown, N.J. The Quakertown silt loam soil had an initial soil $\mathrm{pH}$ of 5.7. Soil $\mathrm{pH}$ was measured using a 1 soil : 1 water volume ratio in May 2000 before amending the soil with either $\mathrm{CaCO}_{3}$ or $\mathrm{CaSiO}_{3}$ at the rate of 7840 $\mathrm{kg} \cdot \mathrm{ha}^{-1}$ of calcium carbonate equivalent. Soil $\mathrm{pH}$ was measured again using the same method on samples collected from each plot in Dec. 2001. Each year before planting, $280 \mathrm{~kg} \cdot \mathrm{ha}^{-1}$ of $20 \mathrm{~N}-4 \mathrm{P}-8 \mathrm{~K}$ and $1 \mathrm{~kg} \cdot \mathrm{ha}^{-1}$ of B were broadcast. Pumpkin was direct seeded as a single row into the center of each $6 \times 9-\mathrm{m}$ plot on 20 June 2000 and 11 June 2001. In 2000, Command $3 \mathrm{ME}\left(877 \mathrm{~mL} \cdot \mathrm{ha}^{-1}\right)$ was broadcast as a preemergence application, and Permit DF (46 $\mathrm{g} \cdot \mathrm{ha}^{-1}$ ) was applied postemergence for weed control, whereas, in 2001, Command 4E (877 $\left.\mathrm{mL} \cdot \mathrm{ha}^{-1}\right)+$ Prefar $4 \mathrm{E}\left(14 \mathrm{~L} \cdot \mathrm{ha}^{-1}\right)+$ Sonalan $3 \mathrm{E}$ $\left(2.3 \mathrm{~L} \cdot \mathrm{ha}^{-1}\right)$ were applied as a preemergence application for weed control. Following seeding, Furadan 4F $\left(966 \mathrm{~g} \cdot \mathrm{ha}^{-1}\right)$ and Ultra Flourish 2E $\left(3.5 \mathrm{~L}^{-h^{-1}}\right)$ were applied each year in a $0.3-\mathrm{m}$ band over the row for insect and damping-off control, respectively. After thinning, there were six hills (two plants/hill) per plot with a spacing of $0.6 \mathrm{~m}$ between hills. When vines began to run, the plants received a sidedress application of $98 \mathrm{~kg} \cdot \mathrm{ha}^{-1}$ of $\mathrm{N}$.

The fungicide treatment consisted of chlorothalonil (Bravo Weatherstik 6F, 3.5 $\mathrm{L} \cdot \mathrm{ha}^{-1}$ ) + myclobutanil (Nova 40W, 175 $\mathrm{g} \cdot \mathrm{ha}^{-1}$ ) alternated with maneb (Maneb 75DF, $\left.2.24 \mathrm{~kg} \cdot \mathrm{ha}^{-1}\right)+$ copper hydroxide (Champ DP, $\left.1.5 \mathrm{~kg} \cdot \mathrm{ha}^{-1}\right)$. Fungicides were applied with a tractor-mounted sprayer having an offset boom with seven nozzles (TXA88004VK) spaced $0.5 \mathrm{~m}$ apart, and delivered $683 \mathrm{~L} \cdot \mathrm{ha}^{-1}$ at 414 $\mathrm{kPa}$. Fungicide applications were initiated once one powdery mildew lesion was detected in a sample of 50 mature leaves, then repeated on a 7-10 d schedule through September. A total of seven and six applications were made in 2000 and 2001, respectively. The fungicide treatment was applied to half of the plots as a 2 $\times 2$ factorial, and the experiment was conducted as a completely randomized design with four replications.

Rainfall (cm) was 9.8 in June, 9.2 in July, 14.1 in Aug., and 11.4 in Sept. 2000; and 18.3 in June, 10.4 in July, 3.6 in Aug., and 0.4 in Sept. 2001. Supplemental irrigation was applied as needed with an overhead retractable gun in the amount of $14 \mathrm{~mm} /$ application.

In 2000 , for the majority of the disease 
evaluations, the severity of powdery and downy mildew was rated in all plots as the percentage of leaves in the plot area with symptoms. Leaf vigor and disease ratings in 2000 were taken $12 \mathrm{~d}$ before pumpkin harvest. Leaf vigor was rated as a visual estimation of the percent of the total plot area with leaves remaining on 21 Sept. 2000. On 10 Aug. 2001, the number of powdery mildew lesions per leaf was determined based on counts taken from 10 randomly selected leaves per plot. On 6 and 28 Aug. and 26 Sept. 2001, a visual estimation of the percentage of leaves in the plot that were infected with powdery mildew was determined. Bacterial leaf spot developed in 2001 and spread rapidly throughout the plots precluding the possibility of collecting data on leaf vigor for that year.

All fruit with at least $50 \%$ of the surface orange in color were harvested from each plot on 3 Oct. 2000 and 28 Sept. 2001. Fruit were separated into marketable and nonmarketable quality and weighed. Fruit without decay and with intact, firm stems were considered marketable.

It was not possible to collect unsoiled leaf tissue samples from field-grown plants to determine Si uptake. For this purpose, soil was collected on 10 Dec. 2000 from the surface $10 \mathrm{~cm}$ of each plot and placed in 12-L pots to grow 'Howden' pumpkin in the greenhouse for $32 \mathrm{~d}$. Each pot contained two plants and was fertilized at planting with $0.53 \mathrm{~g}$ of $\mathrm{NH}_{4} \mathrm{NO}_{3}$ and $23 \mathrm{~d}$ later with $1.4 \mathrm{~g}$ of $\mathrm{KNO}_{3}$ per pot. Plant material was sampled $32 \mathrm{~d}$ after planting for tissue analysis by collecting the biomass above the third node. Samples were dried at $70{ }^{\circ} \mathrm{C}$ for $48 \mathrm{~h}$, ground to pass a $1-\mathrm{mm}$ sieve, and sent to the Univ. of Florida soil test lab for determination of Si concentration using the method of Elliott and Snyder (1991).

Immediately following fruit harvest in 2001, soil samples were taken by collecting eight cores from the surface $15 \mathrm{~cm}$ of soil in each plot. Soil tests for $\mathrm{Si}$ were performed by the Univ. of Florida soil test lab using the method of Korndorfer et al. (2001).

Experimental data was subjected to analysis using the general linear model (GLM) procedures of SAS (SAS Institute, Cary, N.C.) to determine differences in crop yield, disease severity, plant tissue analysis, and soil $\mathrm{pH}$. Single-degree-of-freedom contrasts were tested for treatment effects (Steel and Torrie, 1980).

\section{Results and Discussion}

Silicon amendment of the soil increased pumpkin yield in only one of the two experimental years (Table 1). In 2000, fruit number was $45 \%$ higher and tonnage was $60 \%$ higher on plots amended with $\mathrm{CaSiO}_{3}$ as compared to $\mathrm{CaCO}_{3}$. Silicon amendment did not increase fruit size. In 2001, bacterial leaf spot resulted in considerable defoliation. The disease likely reduced yield and the potential for silicon treatment to influence yield. Bacterial leaf spot was not influenced by either silicon or fungicide treatment and it had infested $68 \%$ of the leaf area by 26 Sept. 2001.

Table 1. Yield of 'Howden' pumpkin in response to silicon amendment of soil fungicide ${ }^{z}$ application in 2000 and 2001.

\begin{tabular}{lcccccc}
\hline & \multicolumn{6}{c}{ Pumpkin yield } \\
\cline { 2 - 7 } & $\begin{array}{c}\text { No. } \\
\text { fruit/ha }\end{array}$ & $\begin{array}{c}\text { Yield } \\
\left(\mathrm{Mg} \cdot \mathrm{ha}^{-1}\right)\end{array}$ & $\begin{array}{c}\text { Avg fruit } \\
\text { wt (kg) }\end{array}$ & $\begin{array}{c}\text { No. } \\
\text { fruit/ha }\end{array}$ & $\begin{array}{c}\text { Yield } \\
\left(\mathrm{Mg} \cdot \mathrm{ha}^{-1}\right)\end{array}$ & $\begin{array}{c}\text { Avg fruit } \\
\text { wt (kg) }\end{array}$ \\
\hline $\mathrm{CaCO}_{3}$ & 897 & 7.5 & 8.4 & 1076 & 7.2 & 6.7 \\
$\mathrm{CaSiO}_{3}$ & 1328 & 13.3 & 10.0 & 1041 & 7.7 & 7.4 \\
$\mathrm{CaCO}_{3}+$ fungicide & 942 & 8.8 & 9.3 & 1346 & 10.7 & 7.9 \\
$\mathrm{CaSiO}_{3}$ + fungicide & 1346 & 13.0 & 9.6 & 1390 & 9.6 & 6.9 \\
& \multicolumn{7}{c}{$P>\mathrm{F}$} & & \\
Silicon & 0.01 & 0.004 & 0.12 & 0.98 & 0.77 & 0.45 \\
Fungicide & 0.83 & 0.76 & 0.75 & 0.07 & 0.04 & 0.51 \\
$\mathrm{Si}$ * Fung. & 0.92 & 0.58 & 0.13 & 0.80 & 0.53 & 0.09 \\
cv\% & 26 & 29 & 15 & 27 & 29 & 15 \\
\hline
\end{tabular}

${ }^{2}$ Fungicide $=$ chlorothalonil $\left(\right.$ Bravo Weatherstik $\left.6 \mathrm{~F}, 3.5 \mathrm{~L}^{2} \mathrm{ha}^{-1}\right)+$ myclobutanil (Nova 40W, $175 \mathrm{~g} \cdot \mathrm{ha}^{-1}$ ) alternated with maneb (Maneb 75DF, $2.24 \mathrm{~kg} \cdot \mathrm{ha}^{-1}$ ) + copper hydroxide (Champ DP, $\left.1.5 \mathrm{~kg} \cdot \mathrm{ha}^{-1}\right)$. A total of six applications were made during each year.

Table 2. Leaf vigor and percent leaf coverage with powdery and downy mildew on pumpkin in response to silicon amendment of soil and fungicide ${ }^{z}$ application on 21 Sept. 2000

\begin{tabular}{lccc}
\hline Treatment & Leaf vigor & Powdery mildew & Downy mildew \\
\hline & $----\%----$ & $-----\%$ Disease & incidencey-------- \\
$\mathrm{CaCO}_{3}$ & 18.0 & 99 & 97 \\
$\mathrm{CaSO}_{3}$ & 39.0 & 94 & 93 \\
$\mathrm{CaCO}_{3}$ + fungicide & 88.0 & 40 & 29 \\
$\mathrm{CaCO}_{3}$ + fungicide & 89.0 & 40 & 52 \\
& & $P<\mathrm{F}$ & \\
Silicon & 0.0003 & 0.56 & 0.05 \\
Fungicide & 0.0001 & 0.0001 & 0.0001 \\
$\mathrm{Si}$ * Fung. & 0.0009 & 0.56 & 0.008 \\
$\mathrm{Si}$ vs. w/o Si & 0.0002 & 0.23 & 0.05 \\
Fung. + Si vs. fung. w/o Si & 0.73 & 1.00 & 0.05 \\
cv\% & 9 & 12 & 13 \\
\hline
\end{tabular}

${ }^{2}$ Fungicide $=$ chlorothalonil $\left(\right.$ Bravo Weatherstik 6F, 3.5 L·ha $\left.{ }^{-1}\right)+$ myclobutanil (Nova 40W, $175 \mathrm{~g} \cdot \mathrm{ha}^{-1}$ ) alternated with maneb (Maneb 75DF, $\left.2.24 \mathrm{~kg} \cdot \mathrm{ha}^{-1}\right)+$ copper hydroxide (Champ DP, $1.5 \mathrm{~kg} \cdot \mathrm{ha}^{-1}$ ). A total of six applications were made during each year.

${ }^{y}$ Visual estimation of the percentage of leaves in the plot that were infected with powdery mildew and downy mildew.

The incidence and severity of powdery mildew was high in both years. The fungicide treatment was highly effective in reducing powdery mildew severity in both years. Fungicide application increased pumpkin yield only in 2001 (Table 1) with a $36 \%$ increase in fruit tonnage. Similar to the effects of silicon treatment in 2000, in 2001 fungicide treatment increased fruit number but not fruit weight. In 2000 , while the fungicide treatment was highly effective in reducing the severity of powdery mildew and downy mildew, the diseases did not appear in the field until late in the season. Therefore, the diseases had little opportunity to reduce overall yield. In 2001, powdery mildew appeared in the plots in early August and did adversely impact yield. Therefore, by reducing the severity of powdery mildew, the fungicide treatment was able to increase yield. While the fungicide treatment was primarily designed for powdery mildew, the addition of Maneb plus copper hydroxide into the program potentially would provide some control of bacterial leaf spot. The impact of the fungicide treatment on bacterial leaf spot may also have contributed to an increase in yield. Fruit tonnage increased by $36 \%$ but fruit size was not affected by fungicide application.

Downy mildew was only present in 2000 , and the fungicide treatment was effective in reducing incidence of downy mildew as well (Table 2). A significant interaction between soil amendments and fungicide indicated that the combination of silicon amendment and fungicide resulted in less of a reduction in incidence of downy mildew than the combination of $\mathrm{CaCO}_{3}$ amendment and fungicide.

When yield increases occurred with of $\mathrm{Si}$ or fungicide treatment, the responses resulted primarily from an increase in fruit number rather than an increase in fruit weight. Fruit number could have been increased as a result of a combination of improved fruit set, a decease in fruit abortion, or a greater degree of orange color development during maturation. In our study, yield of green pumpkins was not determined. Future research should attempt to determine if better maintenance of leaf vigor late in the season was responsible for the increases in fruit number.

In 2000, both silicon and fungicide treatments were effective in retention of leaf foliage based on observation in the field and as indicated by the leaf vigor ratings (Table 2). A significant interaction between soil amendments and fungicide indicated that leaf vigor was improved with silicon amendment alone but the soil amendments were not different 
when combined with fungicide (Table 2). On plots not treated with fungicide, silicon amendment of soil had the effect of delaying foliage senescence. It is not clear from results obtained in 2000 whether this delay in senescence was a result of an effect of $\mathrm{Si}$ on disease activity or crop physiology. Because $\mathrm{Si}$ was able to increase yield in 2000 (Table 1) regardless of fungicide application, the crop response to Si may be a combination of disease suppression and physiological benefit to the crop. Plant tissue analysis performed on pumpkin grown in the greenhouse in spring 2001 on soil taken from these plots in Dec. 2000 showed that the application of $\mathrm{CaSiO}_{3}$ increased $(P=0.0001)$ Si concentration in the plant 5 fold (from $700 \mathrm{mg} \cdot \mathrm{kg}^{-1}$ for $\mathrm{CaCO}_{3}$ to $3500 \mathrm{mg} \cdot \mathrm{kg}^{-1}$ for $\mathrm{CaSiO}_{3}$ ).

In 2001, disease evaluations conducted in August demonstrated trends suggesting that $\mathrm{Si}$ may have a limited influence on suppression of powdery mildew; however, this treatment effect was significant at only about the $10 \%$ level (Table 3). The effect of fungicide on powdery mildew ratings was significant on all dates of observation. The interaction between soil amendment and fungicide for the September disease rating indicated that the combination of silicon amendment and fungicide was more effective than the combination $\mathrm{CaCO}_{3}$ amendment and fungicide.

The initial soil $\mathrm{pH}$ before planting in 2000 was 5.7. Soil $\mathrm{pH}$ measured on soil samples collected in fall 2001 after pumpkin harvest found no significant difference in $\mathrm{pH}$ between plots amended with $\mathrm{CaCO}_{3}(\mathrm{pH}=6.8)$ and those amended with $\mathrm{CaSiO}_{3}(\mathrm{pH}=6.9)$. A soil test performed on this same set of samples showed that extractable $\mathrm{Si}$ increased from 40 to $127 \mathrm{mg} \cdot \mathrm{kg}^{-1}$ with the application of $\mathrm{CaSiO}_{3}$. These results show that both soil amendments

Table 3. Powdery mildew lesions and percent coverage on pumpkin in response to silicon amendment of soil and fungicide ${ }^{2}$ application in 2001.

\begin{tabular}{|c|c|c|c|c|}
\hline Treatment & 10 Aug. & 16 Aug. & 28 Aug. & 26 Sept. \\
\hline & No. lesions & \multicolumn{3}{|c|}{----\% Powdery mildew incidence ${ }^{\mathrm{y}----}$} \\
\hline $\mathrm{CaCO}_{3}$ & 52.2 & 46 & 46 & 71 \\
\hline $\mathrm{CaSiO}_{3}^{3}$ & 8.8 & 24 & 34 & 71 \\
\hline $\mathrm{CaCO}_{3}^{3}+$ fungicide & 0.3 & 10 & 5 & 40 \\
\hline \multirow[t]{2}{*}{$\mathrm{CaSiO}_{3}+$ fungicide } & 0.0 & 10 & 3 & 29 \\
\hline & \multicolumn{4}{|c|}{$P<\mathrm{F}$} \\
\hline Silicon & 0.13 & 0.11 & 0.51 & 0.04 \\
\hline Fungicide & 0.04 & 0.001 & 0.0001 & 0.0001 \\
\hline $\mathrm{Si} *$ Fung. & 0.14 & 0.11 & 0.32 & 0.04 \\
\hline $\mathrm{Si}$ vs. w/o Si & 0.11 & 0.09 & 0.32 & 1.00 \\
\hline Fung. + Si vs. fung. w/o $\mathrm{Si}$ & 0.36 & 1.00 & 0.67 & 0.0001 \\
\hline $\mathrm{cv} \%$ & 183 & 55 & 24 & 11 \\
\hline
\end{tabular}

${ }^{2}$ Fungicide $=$ chlorothalonil $\left(\right.$ Bravo Weatherstik $\left.6 \mathrm{~F}, 3.5 \mathrm{~L}^{\cdot} \mathrm{ha}^{-1}\right)+$ myclobutanil (Nova 40W, $175 \mathrm{~g} \cdot \mathrm{ha}^{-1}$ ) alternated with maneb (Maneb 75D, $2.24 \mathrm{~kg} \cdot \mathrm{ha}^{-1}$ ) + copper hydroxide (Champ DP, $1.5 \mathrm{~kg} \cdot \mathrm{ha}^{-1}$ ). A total of six applications were made during each year.

${ }^{y}$ Visual estimation of the percentage of leaves in the plot that were infected with powdery mildew.

behaved well as liming agents but that $\mathrm{CaSiO}_{3}$ also increased the plant availability of $\mathrm{Si}$. In New Jersey, there is no significant cost difference in applying either material as a liming agent. Thus, the selection of $\mathrm{CaSiO}_{3}$ as a liming material as needed for soil $\mathrm{pH}$ correction has the potential benefits of suppressing powdery mildew and increasing pumpkin yield without increasing the cost of production.

\section{Literature Cited}

Belanger, R.R., P.A. Bowen, D.L. Ehret, and J.G. Menzies. 1995. Soluble silicon. Its role in crop and disease management of greenhouse crops. Plant Dis. 79(4):329-335.

Elliott, C.L. and G.H. Snyder. 1991. Autoclave-induced digestion for the colorimetric determination of silicon in rice straw. J. Agr. Food Chem. 39:1118-1119.

Epstein, E. 1994. The anomaly of silicon in plant biology. Proc. Natl. Acad. Sci. 91:11-17.

Epstein, E. 1999. Silicon. Annu. Rev. Plant Physiol. Plant Mol. Biol. 50:641-659.

Hamel, S.C. and J.R. Heckman. 1999. Impact of mineral silicon products on powdery mildew in greenhouse grown turf. Rutgers Turfgrass Proc. 31:215-219.

Korndorfer, G.H., G.H. Snyder, M. Ulloa, G. Powell, and L.E. Datnoff. 2001. Calibration of soil and plant silicon analysis for rice production. J. Plant Nutr. 24:1071-1084.

Menzies, J., P. Bowen, D. Ehret, and D.M. Glass. 1992. Foliar applications of potassium silicate reduce severity of powdery mildew on cucumber, muskmelon, and zucchini squash. J. Amer. Soc. Hort. Sci. 117:902-905.

Savant, N.K., L.E. Datnoff, and G.H. Snyder. 1997. Depletion of Plant-Available Silicon in Soils: A possible cause of declining rice yields. Commun. Soil Sci. Plant Anal. 28(13\&14):1245-1252.

Steel, R.G.D. and J.H. Torrie. 1980. Principles and procedures of statistics. McGraw-Hill, New York. 